OPEN ACCESS

Edited by:

George Tsiamis,

University of Patras, Greece

Reviewed by:

Diego Segura,

National Institute of Agricultural

Technology, Argentina

Antonios Alekos Augustinos,

Hellenic Agricultural Organisation,

Greece

*Correspondence:

Emilio Hernández

emilio.hernandez.i@senasica.gob.mx;

emiliohortiz@gmail.com

tORCID:

Emilio Hernández

orcid.org/0000-0002-1011-3637

Specialty section:

This article was submitted to

Systems Microbiology,

a section of the journal

Frontiers in Microbiology

Received: 16 March 2020

Accepted: 07 July 2020

Published: 28 July 2020

Citation:

Roque-Romero L, Hernández E, Aceituno-Medina M, Ventura $C$,

Toledo J and Malo EA (2020)

Attractiveness and Sexual

Competitiveness of Anastrepha obliqua Males (Diptera: Tephritidae)

Fed on a Diet Enriched With

Providencia rettgeri.

Front. Microbiol. 11:1777.

doi: 10.3389/fmicb.2020.01777

\section{Attractiveness and Sexual Competitiveness of Anastrepha obliqua Males (Diptera: Tephritidae) Fed on a Diet Enriched With Providencia rettgeri}

\author{
Linnet Roque-Romero' ${ }^{1}$ Emilio Hernández ${ }^{2 *+}$, Marysol Aceituno-Medina ${ }^{2}$, \\ Carmen Ventura ${ }^{2}$, Jorge Toledo ${ }^{3}$ and Edi A. Malo ${ }^{3}$
}

\begin{abstract}
1 Instituto de Biociencias, Universidad Autónoma de Chiapas, Chiapas, Mexico, ${ }^{2}$ Programa Moscafrut SADER-SENASICA, Subdirección de Desarrollo de Métodos, Chiapas, Mexico, ${ }^{3}$ Grupo de Ecología de Artrópodos y Manejo de Plagas, El Colegio de la Frontera Sur, Chiapas, Mexico
\end{abstract}

The West Indian fruit fly, Anastrepha obliqua (Macquart), is the second most important tephritid fruit fly in Mexico, infesting mango, hog plum and guava fruits. To control this pest, the Mexican government has implemented the use of the sterile insect technique (SIT), which involves the mass production, sterilization and release of flies. However, the A. obliqua laboratory males used in SIT are selected to a lesser extent by the wild females during competitiveness tests. The objective of this study was to compare the effects of males fed on fruit fly food enriched with Providencia rettgeri to those in males fed on food alone, assessing male mating competitiveness, capture of females using traps baited with males fed with the enriched diet and sex pheromone components. The results indicated that males fed with the diet enriched with $P$. rettgeri had increased mating competitiveness and captured more females in the field cage tests. However, no difference was observed in the proportion of volatile sex pheromone components identified during the calling of $A$. obliqua males. The results suggest the value of incorporating bacteria into the mass rearing technique of $A$. obliqua adults in order to improve the sexual competitiveness of males from the laboratory compared to wild males.

Keywords: sterile insect technique, sexual competitiveness, field cages, pheromone components, diet

\section{INTRODUCTION}

An important aspect of insect biology that allows these organisms to increase their diversity and abundance is the symbiotic relationships they share with microorganisms that impact directly on their life history traits. Although many of these microorganisms may be commensalist or parasitic (Poveda-Arias, 2019), others play an important role in the nutrition, metabolism and immune protection of their hosts (Dillon and Dillon, 2004; Brune, 2010; Koch and Schmid-Hempel, 2011; Engel and Moran, 2013). Early studies in the Mexican fruit fly, Anastrepha ludens (Loew) were carried out to evaluate resistance or sensitivity to a variety of antibiotics in bacteria isolated from 
this same species (Kuzina et al., 2001) and to test the attractive effect of metabolites produced by bacteria on A. ludens (Martínez et al., 1994). In addition, studies have determined the presence of Wolbachia in Anastrepha species (Mateos et al., 2020), including guava fruit fly, A. striata (Martínez et al., 2012), West Indian fruit fly, A. obliqua (Mascarenhas et al., 2016), South American fruit fly, A. fraterculus (Conte et al., 2019) and sapote fruit fruit fly, A. serpentina (Coscrato et al., 2009). On the other hand, studies have revealed that the gut bacterial community in flies consists mainly of species of the Enterobacteriaceae family (Noman et al., 2020), and that these microorganisms may be involved in nitrogen fixation, nutrition and insect fitness, including mating behavior and sexual competitiveness, reproductive success, longevity, improve the males fitnnes (Gavriel et al., 2011; Hamden et al., 2013; Andongma et al., 2015; Khaeso et al., 2017; Yuval, 2017; Juárez et al., 2019), protection against pathogens and detoxification (Ben-Yosef et al., 2015; Guo et al., 2017).

Some of the species of the Enterobacteriaceae family correspond to Klebsiella, Enterobacter, Providencia, Pectobacterium, Pantoea, Morganella and Citrobacter (Ben-Ami et al., 2010; Aharon et al., 2013). Providencia rettgeri is a gram negative, opportunistic pathogenic bacteria for humans (O'Hara et al., 2000), which has also been reported as pathogenic for Drosophila melanogaster (Galac and Lazzaro, 2011). However, the pathogenicity of $P$. rettgeri in Mediterranean fruit fly, Ceratitis capitata (Wied.) depends on the concentration supplied (Msaad-Guerfali et al., 2018), and previous experiments indicate that $A$. obliqua males can actually increase their sexual competitiveness under laboratory conditions when fed on P. rettgeri (Gómez-Alonso, 2013).

The West Indian fruit fly, A. obliqua (Macquart), is considered one of the most important tephritid fruit flies affecting the fruit production industry in Mexico and many tropical countries of America because it infests mangoes (Mangifera indica L.), hog plum fruits (Spondias spp.), sapodilla (Achras zapota L.), carambola (Averrhoa carambola L., Oxalidaceae) and guava (Psidium guajava L.) (Norrbom and Kim, 1988; HernándezOrtiz, 1992; Birke et al., 2013; Aluja et al., 2014). To avoid or minimize the harmful effects of $A$. obliqua, mango growers must comply with the health and safety standards required by the market, applying an area-wide management approach involving chemical, biological, cultural and sterile insect (SIT) techniques (Reyes et al., 2000). The SIT involves the mass production of 70 million of bisexual pupae of the target species per week, followed by their sterilization and release (Reyes et al., 2000; Domínguez et al., 2010). However, the A. obliqua males used in the SIT are selected for mating by the wild females with a lower frequency (Rull et al., 2012) and, according to that observed for Ceratitis capitata by Lance et al. (2000), could therefore be considered less competitive than the wild males.

The sexual competitiveness of sterile male fruit flies is increased by using different strategies: 1) increasing the protein content in the diet provided during sexual maturation (Yuval et al., 2007); 2) adding the juvenile hormone analog (methoprene) to the adult diets (Pereira et al., 2011; Teal et al., 2013; MuñozBarrios et al., 2016); 3) applying aromatherapy by exposing the males to volatiles of ginger (Zingiber officinale Roscoe)
(Shelly, 2006; Flores et al., 2011) and orange (Citrus sinensis L.) (Charalampos et al., 2012; Segura et al., 2018) oil; and 4) using enriched foods containing Enterobacteriaceae (BenAmi et al., 2010; Gómez-Alonso, 2013; Yuval et al., 2013; Augustinos et al., 2015). In this way, although A. obliqua shows facultative autogeny (Polloni and Da Costa-Telles, 1987), foods with nitrogenous compounds are key for the A. obliqua males to complete sexual maturation and increase their sexual competitiveness. However, insects cannot synthesize some of the protein-forming amino acids. Many insects that feed on plant material rely on symbiotic association with microorganisms for some aspect of their nutrition (Fitt and O'Brien, 1985). Particularly in Dipterans, it has been documented that bacteria in the digestive tract can mitigate this metabolic limitation, providing their host with essential amino acids (Boush and Matsumura, 1967; Douglas, 2009). Gut bacteria facilitate the absorption of some nutrients by providing digestive enzymes, e.g., microbial hydrolases (Ben-Yosef et al., 2008). Previous studies under laboratory conditions indicate that the main benefit of food enriched with bacteria is an increase in the incidence of mating in A. obliqua when males are fed with P. rettgeri (GómezAlonso, 2013). The objective of this study was to evaluate under field cage conditions the effect of an diet enriched with $P$. rettgeri on males mating competitiveness, male attractiveness and pheromone components of A. obliqua.

\section{MATERIALS AND METHODS}

This research was performed in the Methods Development laboratory of the Moscafrut Program (SADER-SENASICA) in Metapa de Dominguez, Chiapas.

\section{Obtaining Insects}

Pupae were obtained from the Moscafrut (SADER-SENASICA) facility, located in Metapa de Dominguez, Chiapas, Mexico, from a colony that had been mass-reared for more of 150 generations (Orozco-Dávila et al., 2014). All of the pupae used in this study were irradiated for $48 \mathrm{~h}$ pre-emergence with $80 \mathrm{~Gy}$ of gamma radiation using a Cobalt 60 source (Toledo et al., 2004). The mass-rearing procedures and conditions followed those described by Artiaga-López et al. (2004). The adults were separated by sex at $2 \mathrm{~d}$ of age. In all experiments, we used 100 male flies per treatment, which were placed in separate acrylic cages $(30 \times 30 \times 30 \mathrm{~cm})$. To replace the dead flies, 500 females were placed in acrylic cages $(30 \times 30 \times 40 \mathrm{~cm})$ for the mating tests. Both males and females were kept at a density of $1 \mathrm{fly}$ per $\mathrm{cm}^{3}$, at $26 \pm 1^{\circ} \mathrm{C}$ and $70-80 \% \mathrm{RH}$ under a photoperiod of 12:12 h (L:D). The photophase began at 07:00 $\mathrm{h}$ and ended at 19:00 h (FAO, 2007).

\section{Obtaining Bacteria}

The bacteria strain of $P$. rettgeri used in this experiment was previously isolated by Gómez-Alonso (2013) from the guts of wild larvae and adult flies obtained from infested hog plum fruits collected in Metapa de Dominguez, Chiapas and indentified in Laboratory of Microbiology of the Instituto Politécnico Nacional 
(IPN) in Mexico City. For the purpose of this study, P. rettgeri was isolated from adults caught in traps loca ted around of Metapa de Dominguez Chiapas $\left(14^{\circ} 50^{\prime} \mathrm{N}, 92^{\circ} 11^{\prime} \mathrm{W}\right)$. A sample of 30 larvae were kept for pupation and adult emergence. Prior to dissection, the insects were superficially disinfected by repeated immersion in solutions of $10 \%$ sodium hypochlorite, $70 \%$ ethanol $(\mathrm{v} / \mathrm{v})$, with a final wash in sterile distilled water. Each of these steps was carried out for 1-min. The larvae were then dissected in sterile conditions under a stereoscopic microscope to obtain the intestines, which were placed in phosphate buffered saline (PBS) and ground using sterile rods. The homogeneous solution of intestinal tracts was then used to make serial dilutions and spread on duplicate plates of nutritive agar (DIBICO, Cuautitlán Izcalli, Mexico City). These plates were incubated at $28^{\circ} \mathrm{C}$ for 1 to 2 days, and each colony type was then categorized and quantified. Pure cultures were obtained and stored at $-70^{\circ} \mathrm{C}$ for further analysis.

The presumptive identification of the isolates was performed by the Analytical Profile Index (API) (BioMerieux, Hazelwood, Mo) and the results had a $>98 \%$ accuracy for $P$. rettgeri (Code API 20E: 027431157). Final identification of the strains was performed by sequencing the $16 \mathrm{~S} r R N A$ gene (1500 bp), for which DNA was obtained from each isolate using the modified technique described by Hoffman and Winston (1987). The isolated bacteria were grown in $20 \mathrm{ml}$ of nutrient broth (DIBICO) and incubated at $28^{\circ} \mathrm{C}$ for $24-48 \mathrm{~h}$ with shaking $(120 \mathrm{rpm})$. The suspension was centrifuged at $8000 \mathrm{rpm}$, and the resulting cell pellet was subjected to chemical breakdown by adding $500 \mu \mathrm{l}$ of lysis solution (Tris- $\mathrm{HCl} 10 \mathrm{mM}, \mathrm{pH}$ 8.0; $1 \mathrm{Mm}$ EDTA; $\mathrm{NaCl}$ $10 \mathrm{mM}$; SDS 1\% Triton X-100), and mechanical breakdown using glass beads $(0.5 \mathrm{~g})$. Next, $200 \mu \mathrm{L}$ of phenol-chloroformisoamyl alcohol (25: 24: 1) was added and the mixture agitated for $3 \mathrm{~min}$ using a vortex and incubated at $-70^{\circ} \mathrm{C}$ for $20 \mathrm{~min}$ before undergoing heat shock at $65^{\circ} \mathrm{C}$ for $30 \mathrm{~min}$. After the incubation, the sample was centrifuged at 14,000 rpm for $5 \mathrm{~min}$, and the supernatant placed in a new tube. To precipitate the DNA, $1 \mathrm{ml}$ of isopropanol was added, and the sample was incubated at $-20^{\circ} \mathrm{C}$ for $20 \mathrm{~min}$ and centrifuged at $14,000 \mathrm{rpm}$ for $10 \mathrm{~min}$. The supernatant was removed and evaporated on a hub (A160 Speedvac) at $45^{\circ} \mathrm{C}$, and the resulting pellet suspended in $30 \mu \mathrm{l}$ of injectable water. DNA integrity was visualized by gel electrophoresis using a $1 \%$ agarose gel.

The PCR amplification of the 16S rRNA gene was conducted using a fragment of the $16 \mathrm{~S} \mathrm{rDNA}$ gene of approximately $1500 \mathrm{bp}$ in length, which was obtained from the DNA amplified using the universal primers 27F ( $5^{\prime}$-AGA GTT TCM TGG CTC AG-3') and 1492R (5'-TAC GGY TAC CTT ACG ACT T-3') (Lane, 1991). The reaction mixture had a final volume of $25 \mu \mathrm{L}$, and included $2.5 \mu \mathrm{L}$ of Buffer (10X) containing $\mathrm{MgCl}_{2}(50 \mathrm{mM}), 1.0 \mu \mathrm{L}$ of dNTPs $(10 \mathrm{mM}), 1.0 \mu \mathrm{L}$ of initiator $27 \mathrm{~F}(0.1 \mathrm{~nm} / \mu \mathrm{L}), 1.0$ initiator $1492 \mathrm{R}(0.1 \mathrm{~nm} / \mu \mathrm{L}), 1.0 \mu \mathrm{L}$ of DNA $(>80 \mathrm{ng} / \mu \mathrm{L})$, and $0.2 \mu \mathrm{L}$ of Taq DNA polymerase (Invitrogen) $(5 \mathrm{U} / \mu \mathrm{L})$. The amplification conditions were an initial denaturation at $94^{\circ} \mathrm{C}$ for $5 \mathrm{~min}$, followed by 25 cycles of $94^{\circ} \mathrm{C}$ for $1 \mathrm{~min}, 57^{\circ} \mathrm{C}$ for $1 \mathrm{~min}, 72^{\circ} \mathrm{C}$ for $1 \mathrm{~min}$, and a final extension step at $72^{\circ} \mathrm{C}$ for $5 \mathrm{~min}$. The amplified product was purified using the GFX PCR DNA and Gel Band Purification kit (GE). DNA integrity was verified by electrophoresis using a $1 \%$ agarose gel. The amplified sequence was obtained using the ABI Prism 3100 (Applied Biosystems) DNA sequencer.

The isolated 16S rDNA gene sequence was compared to the reference sequences deposited in the databases of the National Center for Biotechology Information (NCBI). Alignment of the reference sequences and the query sequence was performed using the ClustalX program v.1.83. Editing and removal of ambiguous sites of the query sequence was performed with the Seaview v.2.01 program. Taxonomic identification of the bacteria was conducted by alignment of the isolated and reference sequences according to the criteria of Rossello-Mora and Amann (2001) and using a 97\% similarity of the 16S $r R N A$ genes based on the similarity matrix following the Myers and Miller (1988) method, implemented in the program MatGAT v.2.1 (Campanella et al., 2003).

\section{Kinetics of Providencia rettgeri Growth}

The viability of the $P$. rettgeri used in our experiments was ensured obtaining bacteria in the logarithmic growth phase. For this, $P$. rettgeri was grown in $100 \mathrm{ml}$ of nutrient broth (DIBICO) and incubated at $35 \pm 2{ }^{\circ} \mathrm{C}$ for $24-48 \mathrm{~h}$ with shaking (120 rpm). The growth kinetics were performed in a culture medium of $100 \mathrm{~mL}$ and the absorbance of inoculum of 0.2 . The growth of $P$. rettgeri was determined by spectrophotometry at $600 \mathrm{~nm}$ (Jenway brand, model 6715, Stone Bibby Scientific Ltd., China) and count by mass dilution. In addition, the absorbance and the quantity of colony forming units (CFU) per ml were correlated. The bacterial concentration was determined by taking $0.2 \mathrm{ml}$ samples of the pure culture to make serial dilutions, of which the dilutions $10^{-4}-10^{-6}$ were seeded in triplicate using the standard plate agar method. The colony forming units (CFU) in the plates with nutrient agar were quantified after $48 \mathrm{~h}$ at $36^{\circ} \mathrm{C}$. The bacterial growth curve was then calculated and the bacterial concentration estimated at different times of growth.

\section{Incorporation of $P$. rettgeri Into the Fly Diet}

The logarithmic phase bacterial culture (Abs $=0.8 \mathrm{~nm}, 720 \mathrm{~min}$ ) was separated from the liquid medium by centrifugation at $8000 \mathrm{rpm}$ for $10 \mathrm{~min}$. The concentration of microorganisms used was $5 \times 10^{4} \mathrm{CFU}$ per gram of food (Gómez-Alonso, 2013). The resulting microorganism pellet was then suspended in $1 \mathrm{ml}$ of sterile distilled water, and this suspension was immediately added to the $\mathrm{Mb}^{\circledR}$ food and mixed until completely homogenized.

The $\mathrm{Mb}^{\circledR}$ food consisted of a mixture of amaranth flour (Amaranthus cruentus L.), refined sugar and peanuts (Arachis hipogaea L.). It contained $10.19 \%$ protein, had a $\mathrm{pH}$ of 6.15 UI (Hernández et al., 2010), and was developed to feed the adults of Anastrepha spp. during sexual maturation under confined conditions in the facility, for subsequent release in application of the SIT.

\section{Feeding the Flies}

Males were fed with diet corresponding to each treatment: $\mathrm{Mb}^{\circledR}$ food or $\mathrm{Mb}^{\circledR}$ food enriched with $P$. rettgeri. The laboratory females were fed with $\mathrm{Mb}^{\circledR}$ enriched with the bacteria. The $\mathrm{Mb}^{\circledR}$ food enriched with the bacterium $P$. rettgeri was renewed every two days, since this is the length of time for which the $>50 \%$ 
bacterial cells remain viable (living cells capable of reproducing) in the food (Gómez-Alonso, 2013).

\section{Experimental Design}

The evaluation under field cage conditions of the effect of diet enriched with $P$. rettgeri on males mating competitiveness, attractiveness capture and pheromone components of A. obliqua was performed according to 3 -factors experimental desing for sexual competitiveness and attractiveness. Factor 1: Diet with and without bacteria. Factor 2: Age (8-10 days old) of the males,. Factor 3: Cohort, 1, 2, 3, and 4. The variables reponse corresponded to the percentage of matings to determine the effect of the treatments on the sexual competitiveness, the percentage of flies caught in traps in a field cage to evaluate attractiveness. Three replicates were performed for each treatment. The effect on the pheromone compounds was evaluated in a design in blocks, the factor corresponded to the diet with and without bacteria and the age ( 8 and 9 days old) of the males was considered as blocks. The area under each peak was determined, and this was the variable analyzed in order to assess the effect of diet on the sex pheromone components. Four replicates were performed for each treatment.

\section{Sexual Competitiveness Tests in Field Cages}

The tests of sexual competitiveness, capture and analysis of volatiles were carried out after the flies were 8 days old, in order to ensure sexual maturity, which was determined by observing the characteristics of this phase: vigorous fluttering and dilatation of the pleural glands (males) and the presence of eggs (females) (Aluja, 1993).

This test was performed in a field cage of $3 \mathrm{~m}$ in diameter and $2 \mathrm{~m}$ in height, supported by a metal structure and covered with a mesh cloth. An orange tree was placed in the center of the field cage to simulate a natural environment. The test was performed with sexually mature flies of four cohorts, flies of thre differents ages (8-10 days old) (all flies emerged on the same date) of each cohort, three replicates each $(n=3)$, for a total of 36 experimental units for each treatment.

Mating of the males fed with the $\mathrm{Mb}^{\circledR}$ enriched with P. rettgeri was compared to that of the males fed on the $\mathrm{Mb}^{\circledR}$ alone. The males were marked in the upper thorax with non-toxic vinyl paint (Vinci de Mexico, S.A. de C.V., Mexico City), with different colors denoting the different treatments (Meza-Hernández and Díaz-Fleischer, 2006). For each cage, 25 males from each group (treatment and control) were introduced into the field ca ges, with 30 females introduced $15 \mathrm{~min}$ later. Thus, there was a total of 80 insects per cage every day. The observation time lasted from 6:30 am to 10:00 am, which corresponds to the period of maximum sexual activity for A. obliqua (Aluja et al., 2009), and mating pairs were removed from the field cage for scoring the treatments.

\section{Attractiveness Capture Test in Field Cage}

This test was performed in field cages, as described above, using sexually mature flies of 8-10 days of age. Three Multilure ${ }^{\circledR}$ traps were distributed randomly in the branches of the tree within the field cage. The traps were adapted into the inside of the lid with a basket made of tulle mesh and, within these baskets, 10 males from each treatment were confined, including a trap containing males feeding on the $\mathrm{Mb}^{\circledast}$ enriched with $P$. rettgeri, another containing males feeding on $\mathrm{Mb}^{\circledast}$ food alone and an empty third trap included as a control. At the base of the traps was a diluted solution of water and neutral soap in which to capture the visiting females. After $15 \mathrm{~min}, 30$ females were released into the cage field in order to capture the sexually mature females attracted by the call of the males in the Multilure ${ }^{\circledast}$ traps. The observation time was from 6:30 am to 10:00 am, and the number of females captured by each treatment was scored. The test was performed with sexually mature flies of four cohorts, flies of three differents ages (8-10 days old) (all flies emerged on the same date) of each cohort, three replicates each $(n=3)$, for a total of 36 experimental units for each treatment.

\section{Identification of the Pheromone Components}

The sex pheromone was collected for two consecutive days using sexually mature males of 8 and 9 days of age after emerging from the same batch. Four batches of flies were used. Collection was performed at room temperature $\left(25^{\circ} \mathrm{C}\right)$ in the Chemical Ecology Laboratory of ECOSUR. We used 10 males from each treatment, which were placed in $300 \mathrm{ml}$ flasks that were completely sealed to prevent escape of the volatile of interest. The conditioned) needle of the Solid-phase microextraction (SPME) syringe was introduced into the flask to expose the polydimethylsiloxane/divinylbenzene (PDMS/DVB, Supelco, Bellefonte, PA, United States) fiber in order to collect the volatiles emitted by the males. Collection was conducted from 7:00 am to 10:00 am, covering the period of calling in the A. obliqua male. A total of 11 replicates were performed for each age and treatment.

Analysis of the volatiles was performed on a gas chromatograph coupled to a mass spectrometer (GC-MS) (CP-3800 Varian, Palo Alto, CA, United States) using a fused silica capillary column VF-5MS $(30 \mathrm{~m} \times 0.25 \mathrm{~mm}$ ID Varian, United States). The samples were injected into "splitless" mode. The carrier gas, high-purity helium, was used at a constant flow of $1 \mathrm{ml} \mathrm{min}-1$. The temperature was programmed from $50^{\circ} \mathrm{C}$ for $1 \mathrm{~min}$, increasing at $15^{\circ} \mathrm{C} \mathrm{min}-1$ up to $280^{\circ} \mathrm{C}$, which was maintained for $10 \mathrm{~min}$. The mass spectrometer was operated by electron impact (EI) at $70 \mathrm{eV}$. The transfer line was kept at a constant temperature of $280^{\circ} \mathrm{C}$, while the ionization source was at $180^{\circ} \mathrm{C}$. Exploration of the mass spectra was performed over a range of $\mathrm{m} / \mathrm{z} 40-350$ in SIM mode. The collected volatiles were identified by comparing the retention time and NIST-92 and NIST-98 mass spectrum databases. The area under each peak was determined, and this was the variable analyzed in order to assess the effect of diet on the sex pheromone components.

\section{Statistical Analysis}

Statistical analysis of all data was performed using R software (R version 3.0.3) (R Core Team, 2018). Shapiro-Wilk normality test, Bartlett test of homogeneity of variances indicated that 


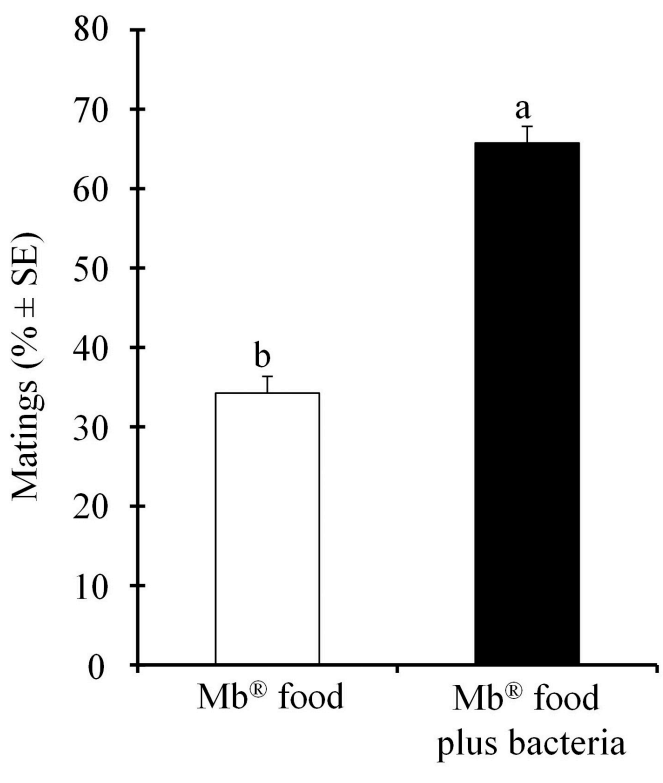

FIGURE 1 | Mean percentages ( \pm SE) of the number of mating Anastrepha obliqua males fed on $\mathrm{Mb}^{\circledR}$ enriched with Providencia rettgeri, compared to the males fed on the $\mathrm{Mb}^{\oplus}$ diet alone, in field cages.

percentages of matings showed normality distribution and homogeneous variances. The data of matings and caught flies were analyzed by the Mixed-Effect model to determine the effect of the cohort and age as random factors, later the same data were analñyzed by a Generalized Linear Model (GLMs) considering a Poison (random) and log distribution. The data for volatile sex pheromone components were subjected to a $t$-test for unequal variances $(\alpha=0.05)$.

\section{RESULTS}

\section{Bacteria Identification}

One isolated colony, which presented 99.6\% $16 \mathrm{~S} \quad r R N A$ gene sequence similarity with $P$. rettgeri (access number: NR042413) from the National Center for Biotechology Information (NCBI) gene bank, was selected. The bacterial identification with API (BioMerieux, Hazelwood, Mo) produced a $>98 \%$ accuracy for $P$. rettgeri (Code API 20E: 027431157). This coincides with the comparison of the isolated 16S rRNA gene with the reference sequences deposited in NCBI.

\section{Sexual Competitiveness Tests in the Field Cage}

We found that the number of mating $A$. obliqua males that were fed with $\mathrm{Mb}^{\circledR}$ food enriched with $P$. rettgeri increased significantly $\left(\chi^{2}=367.36 ;\right.$ df $=1$; $P<0.001)$ compared to those fed on the $\mathrm{Mb}^{\circledR}$ food alone (Figure 1).

\section{Attractiveness Capture Test in the Field Cage}

We found that the Multilure traps baited with the males feeding on the $\mathrm{Mb}^{\circledast}$ enriched with $P$. rettgeri captured significantly $\left(\chi^{2}=2423.32 ; \mathrm{df}=1 ; P<0.001\right)$ more females than the Multilure traps baited with the $\mathrm{Mb}^{\circledR}$ food only (Figure 2). The empty (unbaited) Multilure traps captured the lowest number of females (Figure 2).

\section{Identification of the Pheromone Components}

Analysis of the sex pheromone components by GC-MS showed that the A. obliqua males fed on the $\mathrm{Mb}^{\circledR}$ food enriched with $P$. rettgeri and the males fed only on $\mathrm{Mb}^{\circledR}$ released seven compounds that were identified as $(Z)$-3-nonenol $(t=0.63$; $\mathrm{df}=14 ; P=0.55)$, nonadienol $(t=0.36 ; \mathrm{df}=14 ; P=0.73)$, sesquiterpene $(t=0.97 ; \mathrm{df}=14 ; P=0.35), \beta$-farnesene $(t=0.38$; $\mathrm{df}=14 ; P=0.71),(\mathrm{E}-\mathrm{Z})-\alpha$-farnesene $(t=0.56 ; \mathrm{df}=14$; $P=0.58),(\mathrm{E}, \mathrm{E})-\alpha$-farnesene $(t=0.07 ; \mathrm{df}=14 ; P=0.94)$ and a farnesene isomer $(t=0.18$; $\mathrm{df}=14 ; P=0.84)$ (Figure 3 ), which showed no significant difference in the proportion of pheromone components released between the two treatments.

\section{DISCUSSION}

This study produced three important findings: The first indicated that $A$. obliqua males from the mass-rearing colony fed on the $\mathrm{Mb}^{\circledR}$ food enriched with $P$. rettgeri under field cage conditions presented increased mating compared to the males fed on the $\mathrm{Mb}^{\circledR}$ food alone. The second finding showed that a higher number of females were captured with the Multilure traps baited with males fed on the $\mathrm{Mb}^{\circledR}$ plus $P$. rettgeri diet. The third finding demonstrates that the A. obliqua males that were fed on the $\mathrm{Mb}^{\circledR}$ and $\mathrm{Mb}^{\circledR}$ enriched with $P$. rettgeri diets released the same compounds during their sexual calling and there was no significant difference between the quantities of each compound released by the males treated with the bacterium and by the control males. These results suggest that the $\mathrm{Mb}^{\circledR}$ food enriched with $P$. rettgeri served to improve the sexual competitiveness of the A. obliqua males from the laboratory under field cage conditions. Similar results under laboratory conditions have been reported by Gómez-Alonso (2013), who determined the mating competitiveness of sterile $A$. obliqua and $A$. serpentina males fed on diets enriched with autogenous bacteria, using cages of $30 \times 40 \times 30 \mathrm{~cm}$. The autogenous bacteria are present in the gut of the wild fruit flies and belong to the Enterobacteriaceae family (Behar et al., 2008; Ben-Yosef et al., 2008, 2010; Lauzon et al., 2009; Ben-Ami et al., 2010; Yuval et al., 2013).

Some of the functions attributed to these microorganisms include biosynthesis of nutrients that are minimally available or unavailable in the food (Cohen, 2004), such as essential amino acids, sugars and vitamins (Girolami, 1983). A few microorganisms have the capacity to fix the atmospheric nitrogen used by the organism in vivo in order to construct proteins involved in reproductive activity, i.e., Citrobacter freundii, 


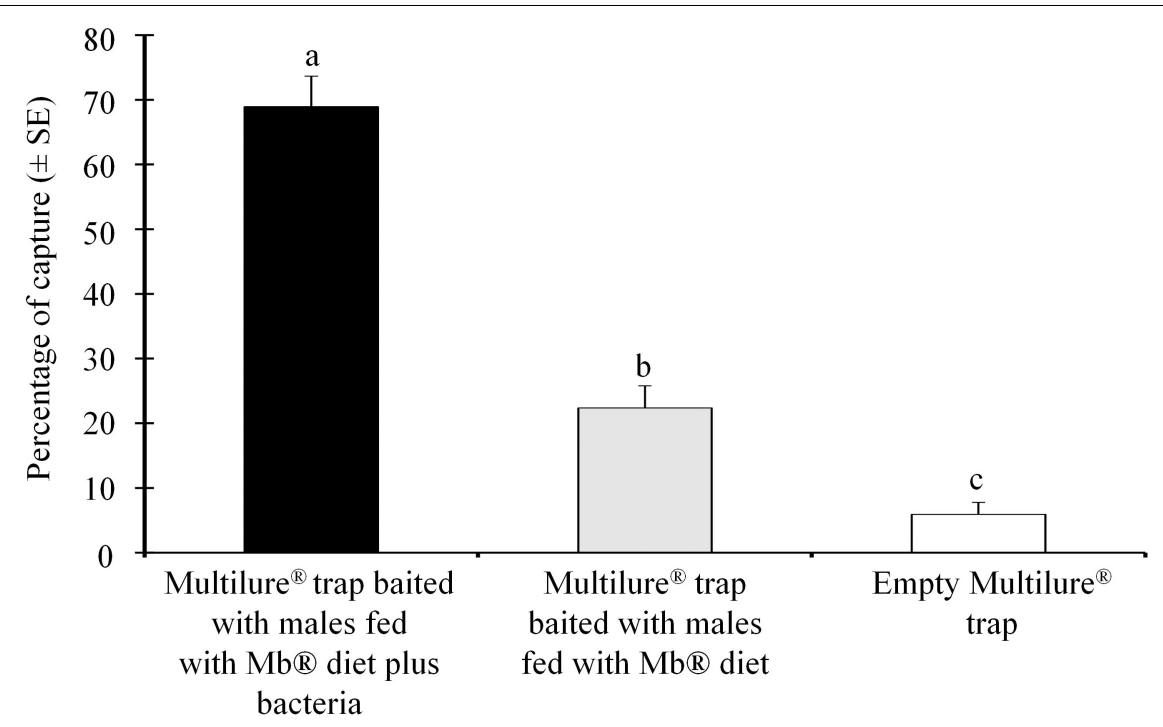

FIGURE 2 | Mean percentages ( \pm SE) of the number of female Anastrepha obliqua captured in Multilure traps baited with males fed on the Mb ${ }^{\circledR}$ enriched with Providencia rettgeri, compared with the those on the $\mathrm{Mb}^{\circledR}$ diet alone as a control.

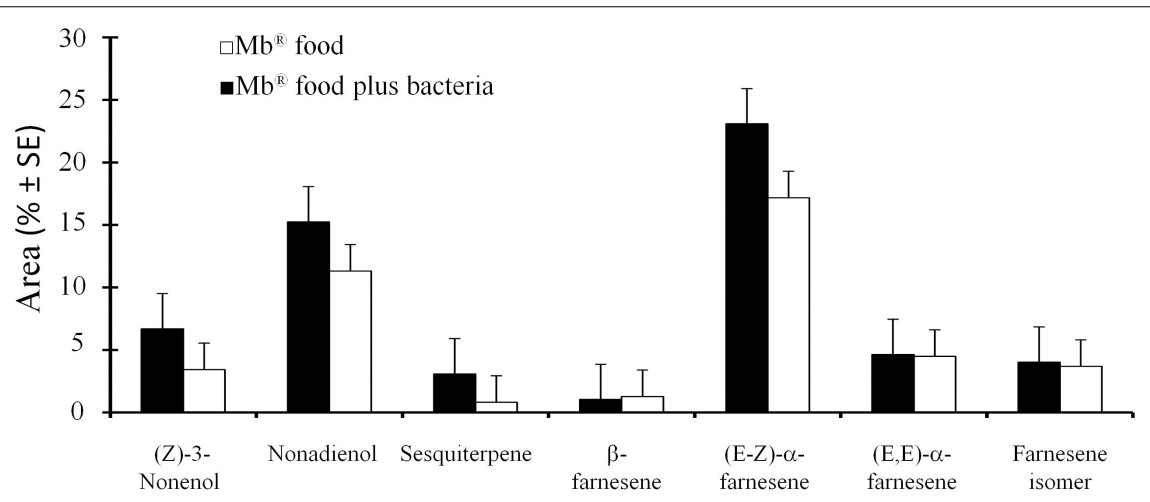

FIGURE 3 | Mean percentages ( \pm SE) of the quantity of volatiles released by the $A$. obliqua males fed on the $\mathrm{Mb}{ }^{\circledR}$ enriched with Providencia rettgeri, and by the males fed on the $\mathrm{Mb}^{\circledR}$ diet alone.

Enterobacter agglomerans, Desulfovibrio spp., Klebsiella spp. and Enterobacter spp. (Nardi et al., 2002; Behar et al., 2005). Providencia rettgeri is a bacterium that is found in the gut of A. ludens (Kuzina et al., 2001) and was recently found in the gut of wild A. obliqua (Gómez-Alonso, 2013). The effects on the number of mating males and the capture of females in A. obliqua adults could be attributed to the essential amino acids, sugar or vitamins biosynthesized by the bacteria that are un available in the diet, or perhaps the $P$. rettgeri provided in the diet did not successfully establish in the gut and its contribution was merely as a nutrient source.

In this study, the volatile compounds found during sexual calling in A. obliqua coincide with those reported by LópezGuillén et al. (2008, 2011) and Chacón-Benavente et al. (2013). Although a significant difference was not found, we observed that the release of ( $Z$ )-3-nonenol, nonadienol, sesquiterpene and (E-Z)- $\alpha$-farnesene consistently increased when the males were fed with food enriched with $P$. rettgeri. In this way, Juárez et al.
(2019) reported ten volatile compounds identified in Anastrepha fraterculus males, and they were significantly affected by the diet. They found that sugar fed males were significantly affected in all compounds released with exception of limonene, suspensolide, $\mathrm{E}, \beta$-ocimene and unknown compound. In addition, in sugar + protein fed males, the authors not found differences (Juárez et al., 2019). Our results are different with those of Juárez et al. (2019), possibly by the lower number of replicates used in the volatile collection.

The hypothesis that food affects attraction, and therefore capture, is in accordance with Sharon et al. (2010), who affirmed that the symbiotic bacteria present in the gut of Drosophila melanogaster influence the production of cuticle hydrocarbons, which in turn modify the mating choice. This could explain the observed preference for mating with their counterparts that present the same type of gut bacteria, but does not explain why the females of A. obliqua that were fed with the food enriched with $P$. rettgeri were captured in greater numbers in 
the traps baited with males that had been fed the same diet. The diet determine the gut bacteria, and this in turn affects major cuticular hydrocarbons (Sharon et al., 2010), that according with Silk et al. (2017) enhance the responses to sex pheromone, as observed for the spruce budworm, Choristoneura fumiferana. The analysis of chemical signals depends on understanding the relationship between social and/or environmental context and the expression of different chemical combinations (Gershman et al., 2014). Although CHCs are not volatile, they can be broken into volatile fragments by reacting with environmental agents (Hatano et al., 2020), which could be used to produce a wide range of compounds as by-products of physiological processes and its regulation during the communication (Gershman et al., 2014).

In summary, in this study, we found that male A. obliqua adults that had been fed with the $\mathrm{Mb}^{\circledR}$ food enriched with $P$. rettgeri presented significantly increased mating and captured more females in the field cages, suggesting that this diet acts to improve the sexual competitiveness of the males and can be used in the SIT.

\section{DATA AVAILABILITY STATEMENT}

The datasets generated for this study are available on request to the corresponding author.

\section{AUTHOR CONTRIBUTIONS}

$\mathrm{EH}$ and MA-M designed the experiment. LR-R, EH, and MA-M performed the experimental work. CV performed molecular identification of the bacteria. JT and EM designed

\section{REFERENCES}

Aharon, Y., Pasternak, Z., Ben-Yosef, M., Behar, A., Lauzon, C., and Yuval, B. (2013). Phylogenetic, metabolic and taxonomic diversities shape Mediterranean fruit fly microbiotas during ontogeny. Appl. Environ. Microbiol. 79, 303-313. doi: 10.1128/AEM.02761-12

Aluja, M. (1993). Unusual calling behavior of Anastrepha robusta flies (Diptera: Tephritidae) in nature. Fla. Entomol. 76, 391-395. doi: 10.2307/3495739

Aluja, M., Arredondo, J., Díaz-Fleischer, F., Birke, A., Rull, J., Niogret, J., et al. (2014). Susceptibility of 15 mango (Sapindales: Anacardiaceae) cultivars to the attack by Anastrepha ludens and Anastrepha obliqua (Diptera: Tephritidae) and the role of underdeveloped fruit as pest reservoirs: management implications. J. Econ. Entomol. 107, 375-388. doi: 10.1603/ec1 3045

Aluja, M., Rull, J., Sivinski, J., Trujillo, G., and Perez-Staples, D. (2009). Male and female condition influence mating performance and sexual receptivity in two tropical fruit flies (Diptera: Tephritidae). J. Insect Physiol. 55, 1091-1098. doi: 10.1016/j.jinsphys.2009.07.012

Andongma, A. A., Wan, L., Dong, Y. C., Li, P., Desneux, N., White, J. A., et al. (2015). Pyrosequencing reveals a shift in symbiotic bacteria populations across life stages of Bactrocera dorsalis. Sci. Rep. 5:9470.

Artiaga-López, T., Hernández, E., Domínguez-Gordillo, J., Moreno, D. S., and Orozco-Dávila, D. (2004). "Mass-production of Anastrepha obliqua at the moscafrut fruit fly facility, Mexico," in Proceedings of the 6th International Symposium on Fruit Fly of Economic Importance, ed. B. N. Brian, (Johannesburg: Heriotdale), 389-392.

Augustinos, A. A., Kyritsis, G. A., Papadopoulos, N. T, Abd-Alla, A. M. M., Cáceres, C., and Bourtzis, K. (2015). Exploitation of the Medfly gut microbiota for the experimental, analyzed the data, and wrote the manuscript. All authors contributed to the article and approved the submitted version.

\section{FUNDING}

This research was funded by the project "The role of the associated bacteria on the biology, rearing and behavior of Anastrepha ludens, A. obliqua, A. serpentina, and A. striata" Contract no. IAEA-17025 and SDM-011/2011-2016 Mexican National Fruit Fly Program/ SENASICA/SAGARPA, as part of the IAEA-CRP "Use of Symbiotic Bacteria to Reduce Massrearing Costs and Increase Mating Success in Selected Fruit Pests in Support of SIT Application 2013-2017."

\section{ACKNOWLEDGMENTS}

We are grateful to Armando Virgen and Bigail Bravo López for their technical assistance. The flies used in this study were provided by the Moscafrut Mass Rearing Facility (Mexican National Fruit Fly Program/ SENASICA/ SADER). We thank two reviewers for their valuable comments.

\section{SUPPLEMENTARY MATERIAL}

The Supplementary Material for this article can be found online at: https://www.frontiersin.org/articles/10.3389/fmicb. 2020.01777/full\#supplementary-material

the enhancement of sterile insect technique: use of Enterobacter sp. in larval diet-based probiotic applications. PLoS One. 10:e0136459. doi: 10.1371/journal. pone.0136459

Behar, A., Yuval, B., and Jurkevitch, E. (2005). Enterobacteria mediated nitrogen fixation in natural populations of the fruit fly Ceratitis capitata. Mol. Ecol. 14, 2637-2643. doi: 10.1111/j.1365-294x.2005.02 615.X

Behar, A., Yuval, B., and Jurkevitch, E. (2008). Gut bacterial communities in the Mediterranean fruit fly (Ceratitis capitata) and their impact on host longevity. J. Insect Physiol. 54, 1377-1383. doi: 10.1016/j.jinsphys.2008.07.011

Ben-Ami, E., Yuval, B., and Jurkevitch, E. (2010). Manipulation of the microbiota of mass-reared Mediterranean fruit flies Ceratitis capitata (Diptera: Tephritidae) improves sterile males sexual performance. ISME J. 4, 28-37. doi: 10.1038/ismej.2009.82

Ben-Yosef, M., Aharon, Y., Jurkevitch, E., and Yuval, B. (2010). Give us the tools and we will do the job: symbiotic bacteria affect olive fly fitness in a dietdependent fashion. Proc. Biol. Sci. 277, 1545-1552. doi: 10.1098/rspb.2009. 2102

Ben-Yosef, M., Jurkevitch, E., and Yuval, B. (2008). Effect of bacteria on nutritional status and reproductive success of the Mediterranean fruit fly Ceratitis capitata. Physiol. Entomol. 33, 145-154. doi: 10.1111/j.1365-3032.2008.00617.x

Ben-Yosef, M., Pasternak, Z., Jurkevitch, E., and Yuval, B. (2015). Symbiotic bacteria enable olive fly larvae to overcome host defences. R. Soc. Open Sci. 2, $150-170$.

Birke, A., Guillén, L., Midgarden, D., and Aluja, M. (2013). "Fruit flies Anastrepha ludens (Loew), A. obliqua (Macquart) and A. grandis (Macquart) (Diptera : Tephritidae): Three pestiferous tropical fruit flies that could potentially expand their range to temperate areas," in Potential Invasive Pests of Agricultural Crops, 
ed. J. Peña, (Wallingford: Centre for Agriculture and Bioscience International), 192-213. doi: 10.1079/9781845938291.0192

Boush, M. G., and Matsumura, F. (1967). Insecticidal degradation by Pseudomonas melophthora, the bacterial symbiote of the apple maggot. J. Econ. Entomol. 60, 918-920. doi: 10.1093/jee/60.4.918

Brune, A. (2010). "Methanogens in the digestive tract of termites," in (Endo) Symbiotic Methanogenic Archaea, ed. J. H. P. Hackstein, (Berlin: Springer), 81-100. doi: 10.1007/978-3-642-13615-3_6

Campanella, J. J., Bitincka, L., and Smalley, J. (2003). MatGAT: an application that generates similarity/ identity matrices using protein or DNA sequences. $B M C$ Bioinform. 4:29. doi: 10.1186/1471-2105-4-29

Chacón-Benavente, R., López-Guillén, G., Hernández, E., Rojas, J. C., and Malo, E. A. (2013). Juvenile hormone analog enhances calling behavior, mating success, and quantity of volatiles released by Anastrepha obliqua (Diptera: Tephritidae). Environ. Entomol. 42, 262-269. doi: 10.1603/en12045

Charalampos, S. I., Papadopoulos, N. T., Kouloussis, N. A., Chrysoula, I. T., and Katsoyannos, B. I. (2012). Essential oils of citrus fruit stimulate oviposition in the Mediterranean fruit fly Ceratitis capitata (Diptera: Tephritidae). Physiol. Entomol. 37, 330-339. doi: 10.1111/j.1365-3032.2012.00847.x

Cohen, A. C. (2004). Insect Diets, Science and Technology. Boca Raton, FL: CRC Press, 324.

Conte, C. A., Segura, D. F., Milla, F. H., Augustinos, A., Cladera, J. L., Bourtzis, K., et al. (2019). Wolbachia infection in Argentinean populations of Anastrepha fraterculus sp1: preliminary evidence of sex ratio distortion by one of two strains. BMC Microbiol. 19(Suppl. 1):289. doi: 10.1186/s12866-019-1652-y

Coscrato, V. E., Braz, A. S., Perondini, A. L. P., Selivon, D., and Marino, C. L. (2009). Wolbachia in Anastrepha fruit flies (Diptera: Tephritidae). Curr. Microbiol. 59, 295-301. doi: 10.1007/s00284-009-9433-9438

Dillon, R. J., and Dillon, V. M. (2004). The gut bacteria of insects: nonpathogenic interactions. Аnnu. Rev. Entomol. 49, 71-92. doi: 10.1146/annurev.ento.49. 061802.123416

Domínguez, J., Artiaga-López, T., Solís, E., and Hernández, E. (2010). "Métodos de colonización y cría masiva," in Moscas de la Fruta: Fundamentos y Procedimientos Para su Manejo, eds P. Montoya, J. Toledo, and E. Hernández, (México City: S y G Editores), 259-276.

Douglas, A. E. (2009). The microbial dimension in insect nutritional ecology. Funct. Ecol. 23, 38-47. doi: 10.1111/j.1365-2435.2008.01442.x

Engel, P., and Moran, N. A. (2013). The gut microbiota of insects-diversity in structure and function. FEMS Microbiol. Rev. 37, 699-735. doi: 10.1111/15746976.12025

FAO (2007). Guidance for Packing, Shipping, Holding and Release of Sterile Flies in Area-Wide Fruit fly Control Programmes, FAO Plant Production and Protection Paper 190. Rome: FAO, 134.

Fitt, G. P., and O’Brien, R. W. (1985). Bacteria associated with four species of Dacus (Diptera: Tephritidae) and their role in the nutrition of the larvae. Oecologia 67, 447-454. doi: 10.1007/BF00384954

Flores, S., Rivera, J. P., Hernández, E., and Montoya, P. (2011). The effect of ginger oil on the sexual performance of Anastrepha males (Diptera: Tephritidae). Fla. Entomol. 94, 916-922. doi: 10.2307/23065849

Galac, M., and Lazzaro, B. P. (2011). Comparative pathology of bacteria in the genus Providencia to a natural host, Drosophila melanogaster. Microbes Infect. 13, 673-683. doi: 10.1016/j.micinf.2011.02.005

Gavriel, S., Jurkevitch, E., Gazit, Y., and Yuval, B. (2011). Bacterially enriched diet improves sexual performance of sterile male Mediterranean fruit flies. J. Appl. Entomol. 135, 564-573. doi: 10.1111/j.1439-0418.2010.01605.x

Gershman, S. N., Toumishey, E., and Rundle, H. D. (2014). Time flies: time of day and social environment affect cuticular hydrocarbon sexual displays in Drosophila serrata. Proc. R. Soc. B 281:20140821. doi: 10.1098/rspb.2014.0821

Girolami, V. (1983). "Fruit fly symbiosis and adult survival: general aspects," in Fruit Flies of Economic Importance, ed. R. Cavalloro, (Rotterdam: A.A. Balkema Publishers), 74-76.

Gómez-Alonso, I. S. (2013). Atributos Biológicos de Machos Estériles de Anastrepha obliqua y Anastrepha serpentina Alimentados con Dietas Enriquecidas con Bacterias Autógenas. 38. B. Sc. Thesis. Universidad Autónoma de Chiapas. Tapachula, Chiapas, México.

Guo, Z., Lu, Y., Yang, F., Zeng, L., Liang, G., and Xu, Y. (2017). Transmission modes of a pesticide-degrading symbiont of the Oriental fruit fly Bactrocera dorsalis (Hendel). Appl. Microbiol. Biotechnol. 101, 8543-8556. doi: 10.1007/ s00253-017-8551-7

Hamden, H., Msaad-Guerfali, M., Fadhil, S., Saidi, M., and Chevrier, C. (2013). Fitness improvement of mass-reared sterile males of Ceratitis capitata (Vienna 8 strain) (Diptera: Tephritidae) after gut enrichment with probiotics. J. Econ. Entomol. 106, 641-647. doi: 10.1603/ec12362

Hatano, E., Wada-Katsumata, A., and Schal, C. (2020) Environmental decomposition of olefinic cuticular hydrocarbons of Periplaneta americana generates a volatile pheromone that guides social behaviour. Proc. R. Soc. $B$ 287:20192466. doi: 10.1098/rspb.2019.2466

Hernández, E., Escobar, A., Bravo, B., and Montoya, P. (2010). Chilled packing systems for fruit fly (Diptera: Tephritidae) in the sterile insect technique. Neotrop. Entomol. 39, 601-607. doi: 10.1590/S1519-566X2010000400021

Hernández-Ortiz, V. (1992). El Género Anastrepha Schiner en México (Diptera: Tephritidae): Taxonomía, Distribución y sus Plantas Huéspedes. Xalapa: Instituto de Ecología y Sociedad Mexicana de Entomología, 165.

Hoffman, C. S., and Winston, F. (1987). A ten-minute DNA preparation from yeast efficiently releases autonomous plasmids for transformation of Escherichia coli. Gene. 57, 267-272. doi: 10.1016/0378-1119(87)90131-4

Juárez, M. L., Pimper, L. E., Bachmann, G. E., Conte, C. A., Ruiz, M. J., Goane, L., et al. (2019). Gut bacterial diversity and physiological traits of Anastrepha fraterculus Brazilian-1 morphotype males are affected by antibiotic treatment. BMC Microbiol. 19(Suppl. 1):283. doi: 10.1186/s12866-019-1645-x

Khaeso, K., Andongma, A. A., Akami, M., Souliyanoh, B., Zhu, J., and Krutmuang, P. (2017). Assessing the effects of gut bacteria manipulation on the development of the oriental fruit fly, Bactrocera dorsalis (Diptera; Tephritidae). Symbiosis. 74, 97-105. doi: 10.1007/s.13199-017-0493-4

Koch, H., and Schmid-Hempel, P. (2011). Socially transmitted gut microbiota protect bumble bees against an intestinal parasite. Proc. Natl. Acad. Sci. U.S.A. 108, 19288-19292. doi: 10.1073/pnas.1110474108

Kuzina, L. V., Peloquin, J. J., Vacek, D. C., and Miller, T. A. (2001). Isolation and identification of bacteria associated with adult laboratory Mexican fruit flies, Anastrepha ludens (Diptera: Tephritidae). Curr. Microbiol. 42, 290-294. doi: $10.1007 /$ s002840110219

Lance, D. R., McInnis, D. O., Rendon, P., and Jackson, C. G. (2000). Courtship among sterile and wild Ceratitis capitata (Diptera: Tephritidae) in field cages in Hawaii and Guatemala. Ann. Entomol. Soc. Am. 93, 1179-1185. doi: 10.1603/ 0013

Lane, D. J. (1991). "16S/23S rRNA sequencing," in Nucleic acid techniques in bacterial systematics, eds E. Stackebrandt, and M. Goodfellow, (New York, NY: Wiley), 115-175.

Lauzon, C. R., McCombs, S. D., Potter, S., and Peabody, N. C. (2009). Establishment and vertical passage of Enterobacter (Pantoea) agglomerans and Klebsiella pneumoniae through all life stages of the Mediterranean fruit fly (Diptera: Tephritidae). Ann. Entomol. Soc. Am. 102, 85-95. doi: 10.1603/008.102.0109

López-Guillén, G., Cruz-López, L., Malo, E. A., Gonzalez-Hernández, H., Llanderal-Cazares, C., López-Collado, J., et al. (2008). Factors influencing the release of volatiles in Anastrepha obliqua males (Diptera: Tephritidae). Environ. Entomol. 37, 876-882. doi: 10.1603/0046-225X

López-Guillén, G., Cruz-López, L., Malo, E. A., and Rojas, J. C. (2011). Olfactory responses of Anastrepha obliqua (Diptera: Tephritidae) to volatiles emitted by calling males. Fla. Entomol. 94, 874-881. doi: 10.1653/024.094. 0423

Martínez, A. J., Robacker, D. C., García, J. A., and Esau, K. L. (1994). Laboratory and field olfactory attraction of the Mexican fruit fly (Diptera: Tephritidae) to metabolites of bacterial species. Fla. Entomol. 77, 117-126. doi: 10.2307/ 3495878

Martínez, H., Toledo, J., Liedo, P., and Mateos, M. (2012). Survey of heritable endosymbionts in southern Mexico populations of the fruit fly species Anastrepha striata and A. ludens. Curr. Microbiol. 65, 711-718. doi: 10.1007/ s00284-012-0223-3

Mascarenhas, R. O., Prezotto, L. F., Perondini, A. L. P., Marino, C. L., and Selivon, D. (2016). Wolbachia in guilds of Anastrepha fruit flies (Tephritidae) and parasitoid wasps (Braconidae). Genet. Mol. Biol. 39, 600-610. doi: 10.1590/ 1678-4685-gmb-2016-0075

Mateos, M., Martinez-Montoya, H., Lanzavecchia, S. B., Conte, C., Guillén, K., Morán-Aceves, B. M., et al. (2020). Wolbachia pipientis associated with 
Tephritid fruit fly pests: from basic research to applications. Front. Microbiol. 11:1080. doi: 10.3389/fmicb.2020.01080

Meza-Hernández, J. S., and Díaz-Fleischer, F. (2006). Comparison of sexual compatibility between laboratory and wild Mexican fruit flies under laboratory and field conditions. J. Econ. Entomol. 99, 1979-1986. doi: 10.1603/0022-049399.6.1979

Msaad-Guerfali, M., Djobbi, W., Charaabi, K., Hamden, H., Fadhl, S., Marzouki, W., et al. (2018). Evaluation of Providencia rettgeri pathogenicity against laboratory Mediterranean fruit fly strain (Ceratitis capitata). PLoS One 13:e0196343. doi: 10.1371/journal.pone. 0196343

Muñoz-Barrios, R., Cruz-López, L., Rojas, J. C., Hernández, E., Liedo, P., GómezSimuta, Y., et al. (2016). Influence of methoprene on pheromone emission and sexual maturation of Anastrepha obliqua (Diptera: Tephritidae) males. J. Econ. Entomol. 109, 637-643. doi: 10.1093/jee/tov404

Myers, E. W., and Miller, W. (1988). Optimal alignments in linear space. Comput. Appl. Biosci. 4, 11-17. doi: 10.1093/bioinformatics/4.1.11

Nardi, J. B., Mackie, R. I., and Dawson, J. O. (2002). Could microbial symbionts of arthropod guts contribute significantly to nitrogen fixation in terrestrial ecosystems? J. Insect Physiol . 48, 751-763. doi: 10.1016/s0022-910(02)00105-1

Noman, M. S., Liu, L., Bai, Z., and Li, Z. (2020). Tephritidae bacterial symbionts: potentials for pest management. Bull. Entomol. Res. 110, 1-14. doi: 10.1017/ S0007485319000403

Norrbom, A. L., and Kim, K. C. (1988). A List of the Reported Host Plants of the Species of Anastrepha (Diptera: Tephritidae). Washington, DC: USDA, 114.

O'Hara, C., Brenner, F. W., and Miller, J. M. (2000). Classification, identification and clinical significance of Proteus, Providencia and Morganella. Clin. Microbiol. Rev. 13, 534-536. doi: 10.1128/CMR.13.4.534

Orozco-Dávila, D., Artiaga-López, T., Hernández, M., del, R., Domínguez, J., and Hernández, E. (2014). Anastrepha obliqua (Diptera: Tephritidae) mass-rearing: effect of relaxed colony management. Int. J. Trop. Insect Sci. 34, S19-S27. doi: $10.1017 /$ S1742758414000058

Pereira, R., Sivinski, J., Shapiro, J. P., and Teal, P. (2011). Influence of methoprene and dietary protein on male Anastrepha suspensa (Diptera: Tephritidae) lipid and protein content. Fla. Entomol. 97, 137-144. doi: 10.1653/024.094.0203

Polloni, Y. J., and Da Costa-Telles, M. (1987). "Anastrepha obliqua oviposition capacity in laboratory- 1. Effects of population density," in Proceeding of the CEC/IOBC International Symposium, ed. R. Cavalloro, (Rome: Balkema Netherlands), 169-178.

Poveda-Arias, J. (2019). Los microorganismos asociados a los insectos y su aplicación en la agricultura. Revista Digital Universitaria 20, 1. doi: 10.22201/ codeic.16076079e.2019.v20n1.a2

R Core Team (2018). R: A Language and Environment for Statistical Computing. Vienna: R Foundation for Statistical Computing.

Reyes, F. J., Santiago, G., and Hernández, P. (2000). "The Mexican fruit fly eradication programme," in Area-Wide Control of Fruit Flies and Other Insect Pests, ed. K. H. Tan, (Penang: Penerbit Universiti Sains Malaysia), 377-380.

Rossello-Mora, R., and Amann, R. (2001). The species concept for prokaryotes. FEMS Microbiol. Rev. 25, 39-67. doi: 10.1111/j.1574-6976.2001.tb00571.x
Rull, J., Encarnación, N., and Brike, A. (2012). Mass rearing history and irradiation affect mating performance of the male fruit fly, Anastrepha obliqua. J. Insect Sci. 12, 45. doi: 10.1673/031.012.4501

Segura, D. F., Belliard, S. A., Vera, M. T., Bachmann, G. E., Ruiz, M. J., Jofre-Barud, F., et al. (2018). Plant chemicals and the sexual behavior of male Tephritid fruit flies. Ann. Entomol. Soc. Amer. 111, 239-264. doi: 10.1093/aesa/say024

Sharon, G., Segal, D., Ringo, J. M., Hefetz, A., Zilber-Rosemberg, I., and Rosemberg, E. (2010). Commensal bacteria play a role in mating preference of Drosophila melanogaster. Proc. Natl. Acad. Sci. U.S.A. 107, 20051-20056. doi: 10.1073/pnas. 1009906107

Shelly, T. E. (2006). "Aromatherapy and Medfly SIT," in Fruit Flies of Economic Importance: From Basic to Applied Knowledge Proceedings of the 7th International Symposium on Fruit Flies of Economic Importance, eds R. L. Sugayam, R. A. Zucchi, S. M. Ovruski, and J. Sivinski, (Salvador: SBPC), 59-69.

Silk, P. J., Eveleigh, E., Roscoe, L., Burgess, K., Weatherby, S., Leclair, G., et al. (2017). Unsaturated cuticular hydrocarbons enhance responses to sex pheromone in spruce budworm, Choristoneura fumiferana. J. Chem. Ecol. 43, 753-762. doi: 10.1007/s10886-017-0871-7

Teal, P. E. A., Pereira, R., Segura, D. F., Haq, I., Gómez-Simuta, Y., Robinson, A. S., et al. (2013). Methoprene and protein supplements accelerate reproductive development and improve mating success of male tephritid flies. J. Appl. Entomol. 137(Suppl. 1), 91-98. doi: 10.1111/j.1439-0418.2010.01 606. $\mathrm{x}$

Toledo, J., Rull, J., Oropeza, A., Hernández, E., and Liedo, P. (2004). Irradiation of Anastrepha obliqua (Diptera: Tephritidae) revisited: optimizing sterility induction. J. Econ. Entomol. 97, 383-389. doi: 10.1603/0022-0493-97.2.383

Yuval, B. (2017). Symbiosis: gut bacteria manipulate host behaviour. Curr. Biol. 27, 746-747. doi: 10.1016/j.cub.2017.06.050

Yuval, B., Ben-Ami, E., Behar, A., Ben-Yosef, M., and Jurkevitch, E. (2013). The Mediterranean fruit fly and its bacteria - potential for improving sterile insect technique operations. J. Appl. Entomol. 137(Suppl. 1), 39-42. doi: 10.1111/j. 1439-0418.2010.01555.x

Yuval, B., Maor, M., Levy, K., Kaspi, R., Taylor, P., and Shelly, T. (2007). Breakfast of champions or kiss of death? survival and sexual performance of proteinfed, sterile Mediterranean fruit flies (Diptera: Tephritidae). Fla. Entomol. 90, 115-122. doi: 10.1653/0015-4040(2007)90[115:bocoko]2.0.co;2

Conflict of Interest: The authors declare that the research was conducted in the absence of any commercial or financial relationships that could be construed as a potential conflict of interest.

Copyright $\odot 2020$ Roque-Romero, Hernández, Aceituno-Medina, Ventura, Toledo and Malo. This is an open-access article distributed under the terms of the Creative Commons Attribution License (CC BY). The use, distribution or reproduction in other forums is permitted, provided the original author(s) and the copyright owner(s) are credited and that the original publication in this journal is cited, in accordance with accepted academic practice. No use, distribution or reproduction is permitted which does not comply with these terms. 